\title{
Strategic Petroleum Reserve
}

\section{Quarterly Report}

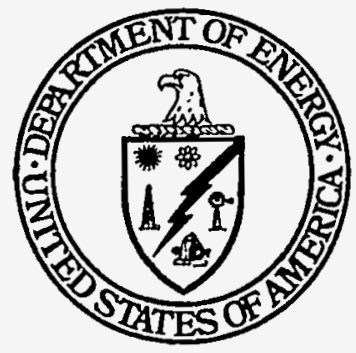

\section{August 15, 1995}

\section{U.S. Department of Energy}

Assistant Secretary for Fossil Energy Office of Strategic Petroleum Reserve Washington, DC 20585

DISTAIBUTION OF THIS DOCUMENT IS UNLIMITED 


\section{DISCLAIMER}

This report was prepared as an account of work sponsored by an agency of the United States Government. Neither the United States Government nor any agency thereof, nor any of their employees, make any warranty, express or implied, or assumes any legal liability or responsibility for the accuracy, completeness, or usefulness of any information, apparatus, product, or process disclosed, or represents that its use would not infringe privately owned rights. Reference herein to any specific commercial product, process, or service by trade name, trademark, manufacturer, or otherwise does not necessarily constitute or imply its endorsement, recommendation, or favoring by the United States Government or any agency thereof. The views and opinions of authors expressed herein do not necessarily state or reflect those of the United States Government or any agency thereof. 


\section{DISCLAIMER}

\section{Portions of this document may be illegible in electronic image products. Images are produced from the best available original document.}




\section{StRategic Petroleum Reserve QUARTERLY REPORT}

AUGUST 15, 1995

U.S. DEPARTMENT OF ENERGY ASSISTANT SECRETARY FOR FOSSIL ENERGY Office of Strategic Petroleum Reserve W A.SHINGTON. D.C. 20585 


\section{TABLE OF CONTENTS}

EXECUTIVE SUMMARY $\ldots \ldots \ldots \ldots \ldots \ldots \ldots \ldots \ldots \ldots \ldots \ldots$

I. STORAGE FACILITIES $\ldots \ldots \ldots \ldots \ldots \ldots \ldots \ldots \ldots \ldots \ldots \ldots \ldots \ldots$

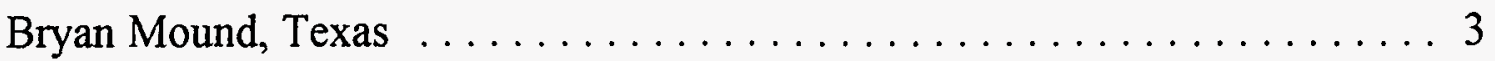

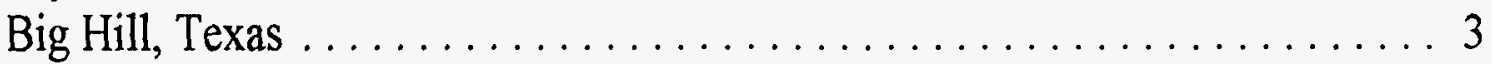

West Hackberry, Louisiana ........................ 4

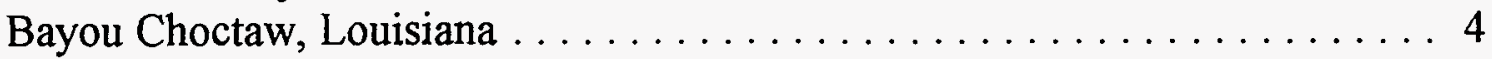

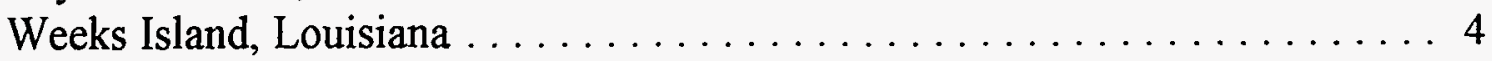

St. James Terminal, Louisiana . . . . . . . . . . . . . . . . . 6

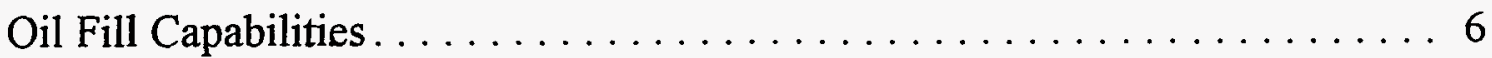

Drawdown/Distribution Capabilities . . . . . . . . . . . . . . 8

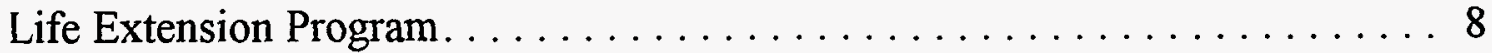

II. OIL ACQUISITION AND FILL $\ldots \ldots \ldots \ldots \ldots \ldots \ldots \ldots \ldots \ldots$

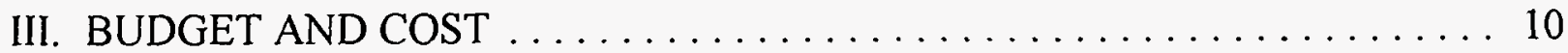

Funds Available For Obligation $\ldots \ldots \ldots \ldots \ldots \ldots \ldots \ldots \ldots$

Storage Facilities Development and Operations and Management (Strategic

Petroleum Reserve Account) . . . . . . . . . . . . . . . 10

Oil Acquisition and Transportation (SPR Petroleum Account) ......... 11

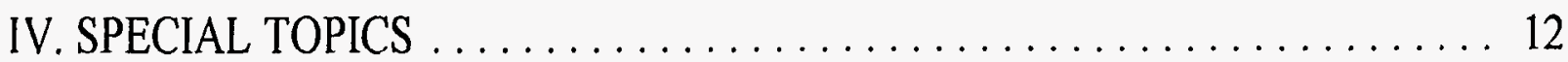

Commercial Use of Strategic Petroleum Reserve Distribution Facilities . . . 12 


\section{LIST OF TABLES}

Page

TABLE I-1 


\title{
STRATEGIC PETROLEUM RESERVE QUARTERLY REPORT
}

\author{
EXECUTIVE SUMMARY
}

The Strategic Petroleum Reserve reduces the Nation's vulnerability to oil supply disruptions. Its existence provides a formidable deterrent to the use of oil as a political instrument and an effective response mechanism should a disruption occur.

The Strategic Petroleum Reserve was created pursuant to the Energy Policy and Conservation Act of December 22, 1975 (Public Law 94-163). Its purposes are to reduce the impact of disruptions in supplies of petroleum products and to carry out obligations of the United States under the Agreement on an International Energy Program. Section 165(a) of the Act requires the submission of Annual Reports and Section 165(b)(1) requires the submission of Quarterly Reports. This Quarterly Report highlights activities undertaken during the second quarter of calendar year 1995, including:

- inventory of petroleum products stored in the Reserve;

- current and projected storage capacity;

- analysis of existing or anticipated problems with the acquisition and storage of petroleum products, and future expansion of storage capacity;

- funds obligated by the Secretary from the SPR Petroleum Account and the Strategic Petroleum Reserve Account during the prior calendar quarter and in total; and

- major environmental actions completed, in progress, or anticipated.

The Department continued to progress in its efforts to correct the Reserve's crude oil inventory problems associated with higher-than-normal gas content and elevated temperatures. Heat exchangers have been installed and are being tested, and degasification operations will commence early next quarter.

The Department continued its investigation of the sinkhole that exists above the salt dome at the Weeks Island site. As a result, the Department's team of experts has concluded that groundwater is entering the Weeks Island storage chamber. Due to increasing risks of uncontrolled water flow into the mine and the potential displacement of oil to the strata above the salt which could cause environmental damage, the Department is developing plans to relocate the crude stored at Weeks Island to other Strategic Petroleum Reserve storage sites and decommission the storage facility. 
The Department is presently pursuing a project to lease or outgrant use of the St. James marine terminal and crude oil pipelines within the Capline, Texoma and Seaway complexes for commercial oil distribution. The Department issued an "Invitation for Offers" on September 30, 1994 inviting industry to submit offers for leasing the St. James terminal and the two Department-owned pipelines within the Capline complex. In response to requests from interested parties, the response date for the Invitation for Offers was extended from October 1994 to February 15, 1995 and the two pipelines were deleted from the solicitation. No lease bids were received. A Strategic Petroleum Reserve Leasing Business Strategy Committee met with interested parties to resolve specific concerns and a revised St. James Terminal lease and bid schedule will be developed. 


\section{STORAGE FACILITIES}

The Department of Energy owns and operates five storage facilities on the Gulf Coasts of Texas and Louisiana for the underground storage of crude oil in salt domes: Bryan Mound and Big Hill in Texas and West Hackberry, Bayou Choctaw, and Weeks Island in Louisiana. These facilities have a combined storage capacity of 750 million barrels. The Department also constructed and operates a marine and pipeline distribution terminal on the Mississippi River in St. James, Louisiana. The following is a summary of the current status of the Strategic Petroleum Reserve's facilities, their respective oil fill and drawdown/distribution capabilities, and the facilities Life Extension Program.

\section{BRYAN MOUND, TEXas}

The Bryan Mound storage facility, near Freeport, Texas, has a storage capacity of 226 million barrels and an inventory of 217 million barrels. The site is available for fill and limited drawdown operations at this time.

The site's drawdown capability has been limited due to the higher than normal gas content and elevated temperatures of the site's crude inventory. In 1994, the Department awarded contracts for degasifying approximately 91 million barrels of crude oil and installing 20 heat exchangers. Installation of the heat exchangers was completed in March 1995. Delta Hudson, the degasification contractor, completed setting of skidmounted degasification units in June 1995. Degassing operations are scheduled to begin in August 1995, with completion about April 1998.

The Government has experienced significant contractor performance problems and delays in the completion of the site's brine disposal pipeline replacement. During the quarter, the Government initiated action to terminate the contractor for default by issuing the contractor a "show cause" notice. At the end of the quarter, the contractor was negotiating with another firm to complete the work. Remaining work consists of aligning and connecting the diffuser segment to the new offshore pipeline, installing the diffuser nozzles, hydrotesting the system and burying the offshore portion of the pipeline.

\section{Big HILl, TeXaS}

The Big Hill storage facility near Winnie, Texas, has a storage capacity of 160 million barrels and an inventory of 43 million barrels. The site is available for fill and drawdown operations.

The site's drawdown capability is currently limited due to the higher than normal 
gas content of the site's crude inventory. The Department's contract for degasification provides for degasifying approximately 26 million barrels of crude oil at the Big Hill site. Degasification of affected Big Hill inventory is scheduled to begin in August 1996, with completion about May 1997.

Big Hill has been operating with potable city water since the end of May 1995 when the system was certified by Texas.

\section{WEST HACKBERRY, LOUISIANA}

The West Hackberry storage facility in Cameron Parish, Louisiana, has a storage capacity of 219 million barrels and an inventory of 204 million barrels. The site is available for fill and limited drawdown operations at this time.

The site's drawdown capability is currently limited due to the higher than normal gas content of the site's crude inventory. The Department's contract for degasification provides for degasifying approximately 18 million barrels of crude oil at the West Hackberry site. Delta Hudson, the degasification contractor, has completed setting all the major equipment during this quarter. Degasification at the site is scheduled to begin in mid-July 1995, with completion about March 1996.

\section{BAYOU CHOCTAW, LOUISIANA}

The Bayou Choctaw storage facility in Iberville Parish, Louisiana, has a storage capacity of 75 million barrels and an inventory of 52 million barrels. The site is available for fill and limited drawdown operations.

The site's drawdown capability is currently limited due to the higher than normal gas content of the site's crude inventory. The Department's contract for degasification provides for degasifying approximately 9 million barrels of crude oil at the Bayou Choctaw site. During the quarter, work was initiated to prepare the site for future hookup of the Delta Hudson skid-mounted degasification units at Bayou Choctaw. Plans are to move degasification units from West Hackberry upon completion of operations at that site. Degasification at Bayou Choctaw is scheduled to begin in April 1996, with completion about July 1996.

\section{WEEKS ISLAND, LOUISIANA}

The Weeks Island storage facility in Iberia Parish, Louisiana, has a storage capacity of 70 million barrels and is currently filled to capacity. 
In late 1993, the Strategic Petroleum Reserve initiated an investigation into the cause and potential ramifications of a sinkhole that was discovered at the surface above the southeast boundary of the upper level of the oil storage chambers. A Weeks Island Mine Integrity Management Group, consisting of Department of Energy personnel, Sandia National Laboratories geologists, and engineering contractors was formed. This team of experts conducted geotechnical investigations of the sinkhole through surface seismic surveys, tomography seismic surveys, exploratory drilling, and injection of tracer dyes in the region below the sinkhole. As a result, the Department discovered a sediment crevasse 70 feet within the salt formation directly beneath the sinkhole. Further, the Department measured a downward movement of fluids and sediments within the crevasse, which correlates with measurements of brine accumulation in the mine and sediment loss at the surface. This information led the Department to conclude that groundwater is entering the Weeks Island oil storage chamber.

On December 15, 1994, the Department concluded that long term storage of Strategic Petroleum Reserve crude oil at its Weeks Island site poses too great of an environmental risk and that the Weeks Island site should be decommissioned. Plans have been developed and preparations made to relocate the Weeks Island oil to other Strategic Petroleum Reserve storage facilities in Louisiana and Texas during 1995 and 1996 and to complete decommissioning Weeks Island as a Strategic Petroleum Reserve facility by mid-1999.

In preparation for drawing down the mine, the Department elected to construct a freeze wall, i.e. freezing the ground surrounding the sinkhole, to prevent any potential ground water from entering the mine. The Department awarded a contract for the freeze wall construction on April 12, 1995. The contractor will have the wall in place and tested by September 30, 1995. At the end of the quarter, the first of three concentric rings of wells around the sinkhole had been drilled into the top of the salt formation with preparations made to commence freezing operations by mid July. The other two rings are being installed inside the first ring to provide a competent freeze wall before commencing oil movements.

To comply with the National Environmental Policy Act, the Department has initiated the preparation of an Environmental Assessment for the decommissioning of the Weeks Island site. On June 8, 1995, the Department held a public meeting in New Iberia, Louisiana, for the purpose of gathering input from members of the community on identifying additional alternatives and environmental issues to consider in the proposed decommissioning of the Weeks Island site. 


\section{ST. JAMES TERMINAL, LOUISIANA}

The St. James Terminal is located on the Mississippi River in St. James Parish, Louisiana, 45 miles west of New Orleans and 30 miles southeast of Baton Rouge. The terminal provides marine services associated with the fill and drawdown of the Strategic Petroleum Reserve's Bayou Choctaw and Weeks Island storage facilities. In addition, the terminal can distribute crude oil through pipeline connections to two neighboring commercial crude oil distribution terminals, Capline and LOCAP. The terminal is available for both fill and drawdown operations. Plans to lease or outgrant use of the terminai and crude oil pipelines are discussed in the "Special Topics" section of this report.

\section{Oil Fill Capabilities}

As of June 30,1995 , the Reserve had a total storage capacity of 750 million barrels and a crude oil inventory of 592 million barrels. The oil fill capabilities for all the storage facilities are shown in Table I-1. 


\begin{tabular}{|c|c|c|c|c||}
\hline \multicolumn{7}{|c|}{ TABLE I-1 } \\
Strategic Petroleum Reserve Storage Capacity \\
(Figures in Millions)
\end{tabular}




\section{DRAWDOWN/DISTRIBUTION CAPABILITIES}

The Strategic Petroleum Reserve's current physical drawdown and distribution capability is 4.3 million barrels per day. However, due to the problems associated with elevated temperatures and gas build-up in the crude oil inventory, the amount of crude oil available for drawdown is temporarily limited to about 530 million barrels at an initial sustained average rate of 3.1 million barrels per day. The available quantity and drawdown rate will gradually increase as degasification operations proceed beginning in July 1995.

\section{Life EXTENSION Program}

Since most of the Strategic Petroleum Reserve's facilities were originally designed for 20-year operational lives and will be reaching the end of their design lives by the year 2000, the Department initiated a Life Extension Program in 1994. This program will ensure the Reserve's continued mission readiness. The goal of the Life Extension Program is that, by the year 2000, all major Strategic Petroleum Reserve systems will have been upgraded or replaced to extend the useful life of the Strategic Petroleum Reserve facilities and drawdown systems to the year 2025.

The Mitre Corporation, which provides systems engineering support to the Strategic Petroleum Reserve, completed a Comprehensive Life Extension Plan in April 1994. The Comprehensive Life Extension Plan focuses on (a) simplification of site/system configurations by reducing the number of motors, pumps and valves by 30 to 60 percent, (b) improving logistics through standardization of equipment among sites and systems, (c) achieving higher systems availability through the application of more modern, reliable technology, and (d) reducing the annual operating and maintenance cost of Strategic Petroleum Reserve facilities by 10 to 20 percent.

In June 1994, Mitre began preparing conceptual designs for each storage site which will reflect the planned configuration of the sites upon completion of all life extension projects. Conceptual designs for West Hackberry and Bryan Mound were completed during the first quarter of 1995; the remaining conceptual designs for Bayou Choctaw and Big Hill are scheduled for completion during the next quarter. In the meantime, the Strategic Petroleum Reserve has proceeded with detailed design and contract awards for the more critical projects.

Through the quarter, contracts have been awarded for the procurement of cavern isolation valves at Bryan Mound and West Hackberry and control system equipment for Bryan Mound. At Bayou Choctaw, contracts have been awarded for site piping replacement and for lining the pipeline to the site's brine disposal wells. 


\section{OIL ACQUISITION AND FILL}

Due to the lack of funding for fiscal year 1995 crude oil purchases, there were no Strategic Petroleum Reserve crude oil acquisition and fill activities during the second quarter of calendar year 1995 . As of June 30,1995 , the total inventory was $591,672,000$ barrels $(94,058,098$ cubic meters). 


\section{BUDGET AND COST}

This section provides the financial information required by section $165(b)(1)$ of the Energy Policy and Conservation Act, as amended.

\section{FISCAL YEAR 1995 APPROPRIATIONS}

On September 30, 1994, the President signed the Department of Interior and Related Agencies Appropriations Act for FY 1995 (Public Law 103-332) which provided $\$ 243.7$ million for management and operations of the Reserve. These appropriations included $\$ 90.7$ million derived from the transfer of unobligated balances from the SPR Petroleum Account. The Act also included an outlay cap of $\$ 9$ million on use of prior year balances in the SPR Petroleum Account.

\section{Funds AVAILABLe For Obligation}

The Department of the Interior and Related Agencies Appropriations Act for 1995 (Public Law 103-332) provided $\$ 243.7$ million for operations and management of the Reserve. The Strategic Petroleum Reserve Account had \$263.7 million available for obligation in fiscal year 1995, including funds carried over from fiscal year 1994. Total funds available for obligation in the SPR Petroleum Account are \$222.3 million, but are limited by the outlay cap of $\$ 9$ million during fiscal year 1995 .

\section{Storage FaCilities Development AND OPERATIONS AND MANAGEMENT (Strategic Petroleum Reserve ACCount)}

Storage Facilities Development and Operations funding provides for the Strategic Petroleum Reserve facilities program including the construction, operation, and maintenance of the Strategic Petroleum Reserve sites. Management funding provides analyses pertinent to major issues concerning the development and use of the Strategic Petroleum Reserve and for the salaries and expenses necessary to plan and manage the Strategic Petroleum Reserve.

During the third quarter of fiscal year 1995, $\$ 17.8$ million was obligated for Storage Facilities Development, Operations, and Management. Cumulative net obligations for fiscal year 1995 were $\$ 143.4$ million at the end of the third quarter. 


\section{Oil ACquisition ANd Transportation (SPR Petroleum ACCount)}

This activity includes financing for: (1) the Strategic Petroleum Reserve crude oil procurements; (2) associated transportation costs for pipeline and tanker shipments and terminalling; (3) U.S. customs duties and Superfund taxes; and (4) other miscellaneous costs, such as Defense Fuel Supply Center administration costs associated with acquiring and transporting the oil. During a drawdown and sale, this account funds the Federal cost of drawing down Strategic Petroleum Reserve oil from storage and transporting it to the delivery points where purchasers will take title.

During the third quarter of fiscal year 1995, no additional obligations were made from the SPR Petroleum Account. Net disbursements (outlays) from the Account during the same period amounted to approximately $\$ .5$ million.

After transfers to the Strategic Petroleum Reserve Account and Fossil Energy Research and Development as appropriated in fiscal year 1995, the SPR Petroleum Account contains $\$ 222.3$ million of obligational authority for Strategic Petroleum Reserve oil acquisition and transportation. The fiscal year 1995 Department of Interior and Related Agencies Appropriations Act established an outlay ceiling of $\$ 9$ million. 


\section{SPECIAL TOPICS}

\section{Commercial Use of Strategic Petroleum Reserve Distribution Facilities}

The design of the Strategic Petroleum Reserve's crude oil distribution system has been based on a strategy of making maximum use of commercial crude oil distribution facilities and minimizing the development and operation of facilities to be used exclusively by the Strategic Petroleum Reserve. During its development, the Strategic Petroleum Reserve has constructed several crude oil pipelines and one marine terminal to connect its facilities to the commercial infrastructure. With the Reserve approximately 80 percent filled, no acquisition anticipated in the near future, and drawdown only required in the event of a national energy emergency, these facilities are significantly underutilized.

The Department is presently pursuing a project to lease or outgrant use of its distribution facilities, i.e. the St. James marine terminal and crude oil pipelines within the Capline, Texoma and Seaway complexes, for commercial crude oil distribution. Under Section 159(f)(D) of the Energy Policy and Conservation Act, the Secretary of Energy has statutory authority to "use, lease, maintain, sell or otherwise dispose of storage and related facilities" to the extent necessary and appropriate to implement the Strategic Petroleum Reserve Plan. By making these facilities available for commercial use, the Department expects to convert currently idle or partially utilized properties into a source of revenue. It also hopes to save maintenance and other costs associated with keeping the facilities ready for use.

The Department issued an "Invitation for Offers" on September 30, 1994, inviting industry to submit offers for leasing the St. James marine terminal and the two DOEowned pipelines within the Capline complex. The proposed terminal lease contained provisions for the lessee to provide drawdown services for the Federal Government in the event of an energy emergency. The proposed pipeline leases also required that the pipelines be operated as either a State or Federal common carrier, allowing other companies to transport crude after making suitable arrangements with the lease holders.

Based on industry's request, the Invitation for Offers (IFO) response date was extended from November 18, 1994, until February 15, 1995. At this time, the IFOs for the Bayou Choctaw and Weeks Island pipelines were cancelled. On February 15, 1995, the Strategic Petroleum Reserve did not receive any lease bids for the St. James Terminal. Apparent reasons for the nonresponse appear to be concerns over lease terms and conditions, and the uncertainty of adequate business revenues. To understand more fully industry's concerns and problems and develop more mutually beneficial leasing 
arrangements, the Strategic Petroleum Reserve Leasing Business Strategy Committee has met with all interested parties. After reviewing industry concerns, the Strategic Petroleum Reserve is tentatively planning to resolicit leasing proposals for the St. James Terminal and the Bayou Choctaw pipeline in the first quarter of 1996. Leasing actions for the remaining pipelines have been delayed to 1996 due to potential operational requirements associated with the relocation of the Weeks Island crude oil.

In support of leasing the St. James marine terminal, the Department prepared an Environmental Assessment and issued a Finding of No Significant Impact in January 1995. With respect to the leasing of the pipelines, DOE intends to conduct its environmental review in accordance with the competitive procurement provisions of DOE's NEPA Implementation Procedures, 10 CFR 1021.216. 